\title{
De Balanced Scorecard in bedrijf
}

\section{Een overzicht van recent onderzoek}

\section{Tom Groot}

SAMENVATTING De Balanced Scorecard (BSC) is het gesprek van de dag onder controllers. De acceptatiegraad van deze methode in de praktijk ligt duidelijk hoger dan die van bijvoorbeeld Activity-Based Costing. Dit artikel poogt een overzicht te geven van recent onderzoek naar de invoering en het gebruik van de BSC. Daaruit blijkt dat er veel onvermoede problemen bestaan: voor verschillende onderdelen in de organisatie zullen aangepaste BSC's moeten worden gemaakt. Daarnaast kunnen de relaties tussen niet-financiële en financiële indicatoren buitengewoon complex zijn. Ten slotte hebben managers in het algemeen moeite om bij hun plannings- en beheersingsbeslissingen goed rekening te houden met de verschillende dimensies van de BSC.

\section{Inleiding}

De door Kaplan en Norton gepropageerde Balanced Scorecard (BSC) blijkt een succesnummer te zijn. Recent onderzoek wijst uit dat 43\% van 1990 ondervraagde Amerikaanse managers, die overwegend in financiële functies werken, gebruikmaken van de Balanced Scorecard (American Institute of Certified Public Accountants en Maisel, 2001). Dit is geen louter Amerikaanse trend. Een onderzoek van Ernst \& Young en de American Quality Foundation naar het gebruik van prestatiemaatstaven in 1988 en 1991 door ondernemingen in vier sectoren (automobiel, computer, banken en gezondheidszorg) in de Verenigde Staten, Canada, Japan en Duitsland wijst uit dat de intensiteit van het gebruik van zowel financiële als niet-financiële informatie toeneemt. Daarnaast wordt duidelijk dat managers een steeds groter belang hechten aan informatie over klanttevre-

Prof. Dr. T.L.C.M. Groot is hoogleraar Management Accounting aan de Vrije Universiteit te Amsterdam. denheid en kwaliteit van productiesystemen (IQS, 1991; Ittner en Larcker, 1998b). In 1999 zegt 27\% van 236 onderzochte Scandinavische business unit managers een BSC te gebruiken en kondigt een additionele $34 \%$ aan in twee jaar tijd ook de BSC in te voeren (Kald en Nilsson, 2000). Deze adoptiecijfers liggen duidelijk hoger dan die van Activity-Based Costing.

Een mogelijke reden voor dit succes is wellicht de omstandigheid dat de BSC goed aansluit bij de trend binnen veel organisaties om steeds meer niet-financiële informatie te gebruiken bij de interne besluitvorming. Zo blijkt uit een onderzoek onder 253 topmanagers van grote Amerikaanse (Fortune 500) en Canadese (Post 300) ondernemingen dat zij bij het vaststellen van de strategische doelstellingen van de onderneming een groot gewicht toekennen aan klanttevredenheid en servicegraad (93\% van de respondenten), kwaliteit van productie/producten en dienstverlening (81\%), marktaandeel (79\%) en productiviteit (83\%). Informatie over innovatie en motivatie van personeel wordt aanmerkelijk lager gewaardeerd (Stivers, Covin, Hall en Smalt, 1998). Deze twee categorieën worden ook lager gewaardeerd in een onderzoek onder 100 Zweedse topmanagers (Johansson, Nilsson, Nilsson en Samuelson, 1997) en in een onderzoek onder 236 managers van business units in de vier Scandinavische landen (Kald en Nilsson, 2000). Verrassend is voorts om te zien dat deze niet-financiële prestatiemaatstaven door een groot gedeelte van de Amerikaanse bedrijven die zeggen ze belangrijk te vinden, in onvoldoende mate worden gemeten en gebruikt in de strategische besluitvorming. Er is een grote behoefte aan nieuwe en betrouwbare niet-financiële indicatoren (Stivers et al., 1998). Een onderzoek onder 203 topmanagers in de VS bevestigt dit beeld: klantinformatie wordt belangrijker geacht dan financiële informatie, daarna komen operationele efficiëntie, medewerkerinforma- 
tie, gegevens over positie in de samenleving en innovatie. Ook in dit onderzoek blijkt dat de huidige kwaliteit van met name informatie over klanttevredenheid, efficiëntie, medewerkers, positie in de samenleving en innovatie ronduit slecht is (Lingle en Schiemann, 1996). Kortom, de BSC zou best in een behoefte kunnen voorzien. Dit artikel beoogt een overzicht te geven van recente ervaringen met de BSC en tracht op basis daarvan suggesties te geven hoe de BSC kan worden toegepast. In de volgende paragraaf wordt de Balanced Scorecard kort geïntroduceerd. Daarna bespreken we recent onderzoek aan de hand van drie thema's: wanneer wordt de BSC toegepast (paragraaf 3), wat is de relatie tussen de BSC-dimensies (paragraaf 4) en op welke wijze wordt BSC-informatie gebruikt (paragraaf 5). Ik sluit het artikel af met enkele conclusies in de vorm van aanbevelingen voor de praktijk.

\section{De Balanced Scorecard}

De Balanced Scorecard is een concept van prestatiemeting dat door Robert Kaplan en David Norton is ontwikkeld op basis van een rondetafelconferentie met twaalf succesvolle Fortune 500-ondernemingen. Dit onderzoek vond in 1990 plaats en werd gefinancierd door het 'Nolan Norton Institute', de onderzoeksafde- ling van KPMG. De meerderheid van de twaalf deelnemende bedrijven was actief in de IT-sector ${ }^{1}$. Zij vonden elkaar op de gemeenschappelijke overtuiging dat traditionele accountingmaatstaven voor beoordeling en beheersing van hun organisaties niet meer voldeden. In de rondetafelgesprekken die tweemaal per maand plaatsvonden, werd geprobeerd een nieuw systeem van prestatiemeting te ontwikkelen. Startpunt van de discussies was een model dat het bedrijf Analog Devices had ontwikkeld en dat de naam Corporate Scorecard droeg. Deze corporate scorecard was bedoeld om de voortgang in verbeteringsprojecten zichtbaar en beheersbaar te maken. Het verstrekte naast financiële gegevens ook informatie over ontwikkelingen in levertijden, productkwaliteit, doorlooptijden en effectiviteit van productvernieuwing. In de rondetafelgesprekken hebben de ervaringen met de Corporate Scorecard als uitgangspunt gediend bij de ontwikkeling van een nieuw prestatiemetingsysteem dat de Balanced Scorecard is gedoopt. In de Balanced Scorecard zijn alle mogelijke aspecten van prestatiemeting ondergebracht in een stelsel bestaande uit vier dimensies, namelijk een financiële dimensie, een klantgerichte dimensie, een interne procesgeoriënteerde dimensie en een op vernieuwing en groei gerichte dimensie (Kaplan en Norton, 1992, 1993, 1996a, 1996b). Het geheel is schematisch in figuur 1 weergegeven.

Figuur 1. De Balanced Scorecard (Kaplan \& Norton, 1992)

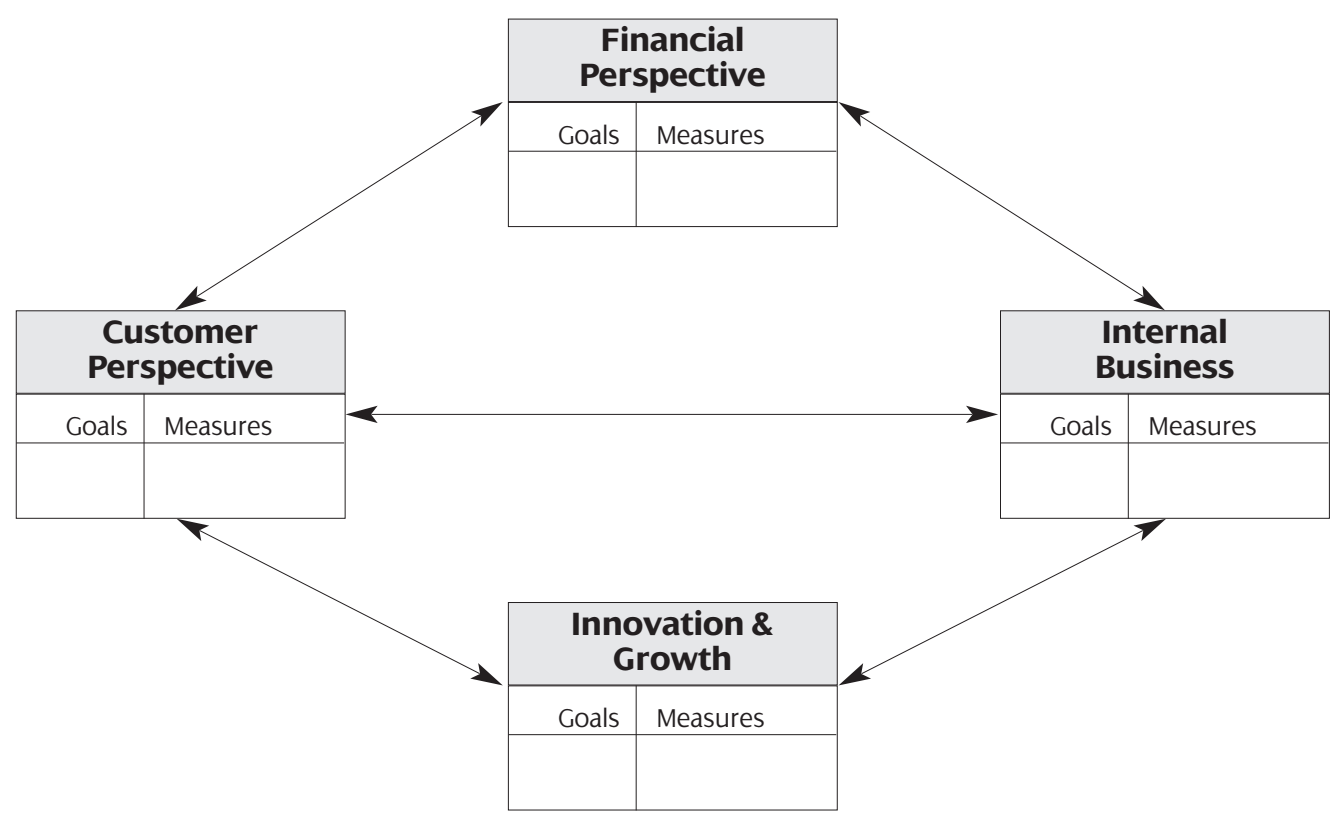


De Balanced Scorecard is bedoeld om op een gestructureerde wijze de strategie van de onderneming te vertalen in concrete doelen ('goals') en de mate waarin deze doelen worden bereikt periodiek te meten ('measures'). De structuur van de BSC kan behulpzaam zijn bij het beperken van de omvang van informatie en het structureren van de informatie naar enkele belangrijke invalshoeken. Deze invalshoeken houden verband met de belangrijke vragen die door managers moeten worden beantwoord, zoals 'wat denken aandeelhouders van ons?' (financial perspective), 'hoe worden we door onze klanten beoordeeld?' (customer perspective), 'waarin moeten we uitblinken om succesvol te zijn?' (internal business) en 'zijn we in staat ook in de toekomst succesvol te zijn?' (innovation and growth). Kaplan en Norton veronderstellen dat er een zekere afhankelijkheid tussen de dimensies van de BSC bestaat. Als het uiteindelijke doel van de ondernemingsleiding is om aantrekkelijk te zijn voor aandeelhouders, dan is het van belang op de markt voor eindproducten goed te presteren. Hiervoor is het nodig dat interne bedrijfsprocessen goed functioneren, hetgeen voor een groot deel afhankelijk is van de mate waarin deze processen tijdig worden verbeterd en vernieuwd. Deze afhankelijkheden geven al aan waar het in de BSC eigenlijk om draait: het vraagt van de managers te expliciteren welke activiteiten er moeten worden ondernomen en welke prestaties er moeten worden geleverd om de strategische doelstellingen van de onderneming te realiseren. Met andere woorden: de BSC is een afbeelding van de causale relaties in het bedrijf. In het ontwerp van een BSC moeten de causale relaties worden geëxpliciteerd, zodat ze gemeten en beheerst kunnen worden. De BSC is een combinatie van allerlei soorten informatie die met elkaar in verband wordt gebracht en waarin een zekere balans moet worden gevonden. De balans in de Balanced Scorecard wordt simultaan op vijf verschillende gebieden gezocht:

1 De vier aandachtsgebieden van de BSC. De BSC van Kaplan en Norton kent vier aandachtsgebieden of dimensies. Dit aantal lijkt vooral een 'grootste gemene deler' te zijn. In de praktijk blijken er bedrijven te zijn die soms met meer en soms met minder dimensies werken. Bovendien zijn niet altijd alle dimensies even belangrijk: afhankelijk van de situatie waarin een bedrijf zich bevindt, de problemen waarmee het wordt geconfronteerd en de strategie die het volgt, kunnen sommige dimensies belangrijker zijn dan andere.

2 Interne en externe prestatiemaatstaven. De BSC leidt er veelal toe dat interne prestatiemaatstaven, zoals inter- ne efficiëntie en kwaliteit van producten, worden aangevuld met externe prestatiemaatstaven die vooral informatie verschaffen over de appreciatie van de onderneming door klanten, vermogensverschaffers en zelfs het publiek in algemene zin.

3 Financiële en niet-financiële maatstaven. De BSC vult financiële maatstaven aan met niet-financiële prestatie-indicatoren. Het is van belang om de relatie tussen deze twee soorten maatstaven te begrijpen en vast te leggen. Niet-financiële prestatiemaatstaven zijn situatiegebonden en kunnen alleen goed worden beoordeeld als ze worden geplaatst in hun eigen context.

4 'Leading' en 'lagging' indicatoren. Een ander verschil tussen financiële en niet-financiële prestatie-indicatoren betreft de volgtijdige afhankelijkheid tussen beide. Financiële prestatiemaatstaven geven een beeld van de prestaties van de onderneming nadat alle activiteiten en transacties achter de rug zijn: het is een evaluatie achteraf en de indicatoren zijn derhalve 'lagging', oftewel vertraagd. De meeste operationele niet-financiële maatstaven geven een beeld van aard, omvang en kwaliteit van handelingen die op dit moment verantwoordelijk zijn voor het financiële resultaat later. Daarom worden deze maatstaven 'leading' indicatoren genoemd: ze veroorzaken de financiële prestaties.

5 Korte- en langetermijnperspectief. De keuze van dimensies en prestatiemaatstaven beïnvloedt eveneens de mate waarin de beoordeling van het functioneren van de organisatie is gericht op de korte dan wel de langere termijn. Zoals we reeds hebben gezien, is een nadeel van louter financiële maatstaven dat zij de aandacht van managers vooral richten op kortetermijnsucces. Verschuiving naar meer niet-financiële prestatiemaatstaven maakt het mogelijk de kortetermijnoriëntatie bij te sturen naar onderwerpen die van belang zijn voor het ondernemingssucces op de middellange en lange termijn.

De BSC is in de ogen van Kaplan en Norton méér dan een prestatiemetingsysteem: het is een strategisch management systeem. De BSC begint namelijk bij de strategie door deze te verduidelijken en in concrete, meetbare doelen te vertalen. Door de geordende wijze waarop de BSC deze doelen weergeeft, wordt het gemakkelijk om ze aan anderen in de organisatie mee te delen. Voor elke doelstelling kunnen streefwaarden worden vastgesteld, al of niet in combinatie met afspraken over beloningssystemen. Duidelijke normen en beloningsafspraken geven het kader aan waarbinnen budgetten, concrete verbeteracties en tijdsplanning van werkzaamheden worden bepaald. Het sluitstuk van de BSC is het moment waarop informatie over resultaten van ondernemingsbeleid in de score- 
cards verschijnt. Omdat op een gestructureerde wijze strategie in acties en meetbare prestatie-indicatoren is vertaald, geeft de informatie van de BSC het management niet alleen de mogelijkheid de kwaliteit van de uitvoering te beoordelen, maar ook te zien of de oorspronkelijke strategie wel adequaat is. Deze gestructureerde wijze van prestatie-evaluatie wordt gezien als de meest belangrijke bijdrage van de BSC aan het strategisch management van ondernemingen.

Het door Kaplan en Norton gepresenteerde BSC-concept is eigenlijk niet meer dan een raamwerk: een lege huls zonder concrete inhoud. Het concept suggereert vier dimensies te gebruiken, maar laat tevens ruimte hiervan af te wijken. De keuze voor de in figuur 1 weergegeven vier dimensies lijkt de grootste gemene deler te zijn van het rondetafeloverleg tussen de twaalf ondernemingen. Alhoewel het een behoorlijke prestatie is om zo'n elegant systeem als de BSC te ontwerpen, de echte innovatie in prestatiemeting wordt toch uiteindelijk overgelaten aan organisaties die de BSC daadwerkelijk invoeren. Deze BSC-gebruikers dienen immers de echt moeilijke beslissingen te nemen, zoals (1) onder welke omstandigheid past men meerdimensionele systemen van prestatiemeting (zoals de BSC) toe, (2) wat is de relatie tussen de verschillende dimensies van de BSC en (3) hoe wordt de BSC in de besluitvorming gebruikt. In het vervolg zullen we elk van deze vragen nader bekijken.

\section{3}

\section{Wanneer gebruikt men systemen als de BSC}

Ondernemingen die een grote nadruk leggen op verbetering van kwaliteit (TQM), blijken hun business units meer op niet-financiële maatstaven zoals interne efficiëntie en medewerkersmotivatie aan te sturen. Deze bedrijven maken bij de prestatiebeoordeling van business unit managers meer gebruik van subjectieve oordeelsvorming (Van der Stede, Chow en Lin, 2000). Ondernemingen die een strategie hanteren van het actief vergroten van marktaandeel gebruiken meer klantinformatie bij de beoordeling van hun business units en voegen deze informatie toe aan al aanwezige financiële informatie (Govindarajan en Gupta, 1985; Van der Stede et al., 2000). Per saldo gebruiken ondernemingen in onzekere omstandigheden dus meer informatie. Deze informatie is in het algemeen meer prospectief, levert meer informatie over de omgeving en is meer subjectief van aard (Gordon en Narayanan, 1984).

Naast de strategie zijn ook andere factoren van belang voor de wijze waarop ondernemingen hun functione- ren waarnemen en beoordelen. Onderzoek uit het einde van de jaren tachtig wijst uit dat de aard van de management accountinginformatie die men gebruikt, samenhangt met het hiërarchisch niveau in de organisatie, de periode die wordt beschouwd en de functie die wordt uitgeoefend. Zo blijken topmanagers van grote Britse bedrijven vooral geïnteresseerd te zijn in financial accountinginformatie, omdat zij ervan uitgaan dat vermogensverschaffers deze informatie gebruiken bij de beoordeling van het bedrijf en het management (Hopper, Kirkham, Schapens en Turley, 1992). Zowel het concernmanagement als de divisies worden op basis van deze financiële maatstaven beoordeeld. De rapportages van divisies aan het concernmanagement zijn eveneens financieel van aard, maar aan deze financiële rapportages worden eveneens niet-financiële, operationele gegevens toegevoegd. Binnen de divisies worden voor de besturing van dagelijkse werkzaamheden management accountinggegevens gebruikt die speciaal voor dit gebruik zijn ontwikkeld en dus in het geheel niet worden beïnvloed door financial accountingvereisten. Divisiemanagers worden in het algemeen beloond op basis van financiële resultaten en op basis van het behalen van aanvullende operationale doelstellingen van niet-financiële aard.

In zijn algemeenheid blijkt dat naarmate managementbeslissingen een kortere tijdshorizon hebben, het gewicht van financiële informatie in de beslissing afneemt (Bruns en Mckinnon, 1993; Mckinnon en Bruns, 1992). Kijken we vervolgens naar dagelijkse beslissingen, dan blijkt dat productiemanagers daarbij vooral op fysieke eenheden letten. Hierbij bestaat een verschil tussen productieafdelingen wier productie op voorraad wordt gelegd (zij letten vooral op arbeidstijd en aantal geproduceerde eenheden) en productieafdelingen die voornamelijk op bestelling produceren (zij letten vooral op bestelhoeveelheid en anwezige voorraad). Inkoopmanagers die in het algemeen worden beoordeeld op kostenbewuste aanschaffingen, letten daarentegen meer op financiële gegevens zoals prijzen en transportkosten. Verkoop en marketing werken veelal met informatie over tijdstip van leveringen, kwaliteit van goederen (klachten) en periodieke overzichten van marktaandelen en algemene economische vooruitzichten. In elk van deze functies domineert andere dan financiële informatie. Dit wil echter niet zeggen dat financiële informatie niet belangrijk is: het uiteindelijke financiële overzicht wordt door alle onderzochte managers als buitengewoon belangrijk aangemerkt. Niet omdat het financiële overzicht nieuwe informatie bevat, maar veeleer omdat het uiteindelijk de bevestiging geeft of, 
en zo ja in hoeverre, de dagelijkse leiding in een bepaalde periode (bijvoorbeeld een maand, kwartaal of halfjaar) succesvol heeft gefunctioneerd.

\section{De relatie tussen niet-financiële en financiële prestaties}

Niet-financiële indicatoren worden vooral gebruikt indien men ervan overtuigd is dat zij goede voorspellers zijn van financiële prestaties. Hierbij gaat het niet om een technisch-vaste, onvermijdelijke relatie, maar veeleer om een empirische relatie met behulp waarvan men waarschijnlijkheidsuitspraken kan doen over toekomstige (financiële) resultaten (zie voor een bespreking Nørreklit, 2000). De vraag is vervolgens of dit bij alle niet-financiële indicatoren ook daadwerkelijk het geval is. De empirische gegevens die momenteel over dit onderwerp beschikbaar zijn, geven een gemengd beeld. Zo blijkt de winstgevendheid van luchtvaartmaatschappijen vooral afhankelijk te zijn van de omvang van activa buiten de vliegdienst (negatieve relatie), de bezettingsgraad van vliegtuigen en het aandeel inkomsten uit ticketverkoop in de totale inkomsten (Schefczyk, 1993). De bezettingsgraad is afhankelijk van de tevredenheid van klanten. De klanttevredenheid kan worden verbeterd door een betere stiptheid van aankomsten, minder overboekingen van stoelen en minder beschadigingen bij de bagageafhandeling (Dresner en Xu, 1995). De financiële resultaten van luchtvaartmaatschappijen kunnen met behulp van twee maanden vertraagde niet-financiële informatie worden voorspeld. Zo worden kosten vooral beïnvloed door klanttevredenheid en beschikbare vervoerscapaciteit, uitgedrukt in ton-mijlen. Omzet wordt vooral bepaald door klanttevredenheid, beladingsgraad van vliegtuigen, marktaandeel en beschikbare vervoerscapaciteit (Behn en Riley, 1999). Uit dit overzicht van luchtvaartmaatschappijen blijkt dat sommige onverwachte factoren, zoals beschikbare vervoerscapaciteit en activa buiten de vliegdienst invloed op financiële prestaties uitoefenen. Tevens worden er verrassende relaties tussen BSC-dimensies ontdekt, zoals de relatie tussen klanttevredenheid en kosten, en de vertraagde invloed van niet-financiële factoren op financiële prestaties.

Uit veel onderzoek blijkt dat klanttevredenheid een belangrijke voorspeller van financiële prestaties is. Tevens blijkt zij invloed te hebben op zowel de kosten als de opbrengsten. Ontevreden klanten lopen weg en geven ruchtbaarheid aan hun klachten. Dit veroorzaakt een teruglopende afzet en derhalve een lagere winstgevendheid. Tevreden klanten kunnen op drie manieren de winstgevendheid vergroten: ze vergroten de afzet door terug te komen voor herhalingsaankopen, ze zorgen door positieve mond-op-mondreclame voor meer nieuwe klanten die niet door dure marketingcampagnes hoeven te worden geworven en ze zijn eerder bereid een hogere prijs voor de producten te betalen. Uit onderzoek dat gebruikmaakt van de PIMS (Proft Impact of Marketing Strategies) database is gebleken dat ondernemingen die zeer goede service verlenen een hoger dan gemiddelde groei van hun marktaandeel realiseren (Buzzell en Gale, 1987), terwijl bedrijven in de top 20\% hoogste servicekwaliteit hun klanten een gemiddeld $8 \%$ hogere prijs in rekening kunnen brengen dan hun onmiddellijke concurrenten (Gale, 1992). De relatie tussen klanttevredenheid en gedrag van individuele consumenten is echter allerminst eenduidig (zie figuur 2, Ittner en Larcker, 1998a, de hier getoonde relatie heeft een vertraging van één jaar, de cijfers zijn afkomstig van klanten van telecommunicatiebedrijven). Zo blijkt deze relatie vooral geldig tussen een onder- en bovengrens van klanttevredenheid. Beneden de ondergrens hebben klanten geen interesse meer, terwijl overschrijding van de bovengrens niet leidt tot verandering van hun koopgedrag. Zowel de ligging van onder- en bovengrenzen als de reacties van individuele klanten buiten deze grenzen zijn per sector verschillend (Zeithaml, Berry en Parasuraman, 1996). Bovendien blijkt binnen deze grenzen de toename van klantenbinding aan de onderneming als gevolg van een hogere klanttevredenheid niet stabiel lineair te verlopen, maar veeleer volgens een grillig patroon van sprongsgewijze aanpassingen. Satisfactieverbetering boven de bovengrens leidt niet tot méér klantentrouw: hier blijken de extra investeringen weggegooid geld te zijn.

Figuur 2. de relatie tussen klanttevredenheid en klantentrouw (Ittner \& Larcker, 1998a)

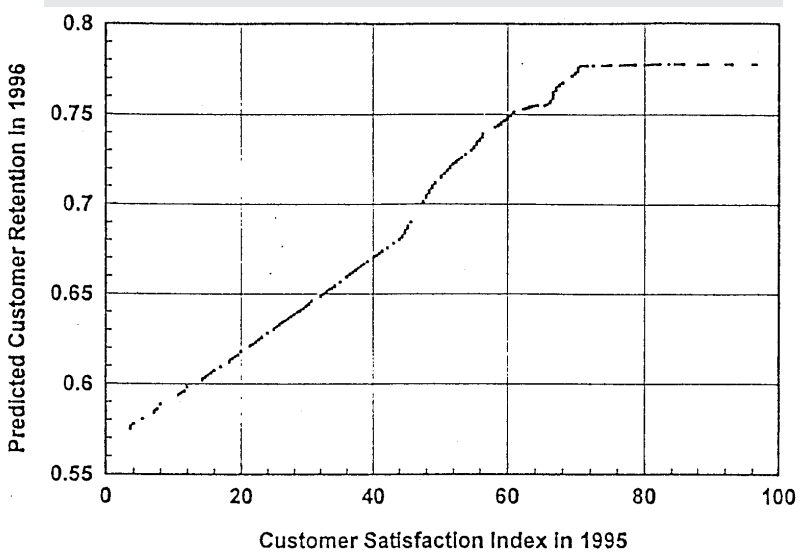


Kijken we naast klanttevredenheid ook naar de tevredenheid van medewerkers, dan toont een studie onder vestigingen van een warenhuisketen aan dat hogere medewerkertevredenheid gerelateerd is aan lagere kosten, terwijl ze tevens leidt tot een toename van klanttevredenheid. Beide leiden aldus tot een hogere netto winst (Banker, Konstans en Mashruwala, 2000). Een analyse van relaties tussen de BSC-dimensies in de ondernemingsprestaties van 75 grote Amerikaanse bedrijven laat zien dat er onverwachte relaties tussen die dimensies blijken te bestaan (Bryant, Jones en Widener, 2000; zie figuur 3 voor een grafische weergave). Zo is de arbeidsproductiviteit ('interne processen') afhankelijk van investeringsuitgaven in gebouwen, machines en technologie (in figuur 3 genoemd 'investeringen in GMT' in de 'innovatie en groei'-dimensie) die twee jaar eerder zijn gedaan. Hier hebben we te maken met vertragingseffecten: het duurt even voordat nieuwe productiesystemen zichtbaar betere prestaties voortbrengen. Er blijkt echter ook een omgekeerde relatie tussen deze twee BSC-dimensies te bestaan: verbeteringen in de arbeidsproductiviteit leiden (met een tweejarige vertraging) tot een toename van het aantal productintroducties. Daarnaast blijken ook causale relaties binnen BSC-dimensies te bestaan. Het aantal productintro- ducties is ook afhankelijk van de uitgaven voor R\&D en het aantal aangevraagde patenten (beide innovatie en groei'). Sommige factoren hebben een dubbele uitwerking op andere, doordat ze zowel één jaar vertraagd als twee jaren vertraagd invloed uitoefenen. Dit geldt bijvoorbeeld voor de invloed van reputatie van producten op het behaalde marktaandeel, en voor de invloed van marktaandeel en arbeidsproductiviteit op de omzet. Ten slotte zien we hier het merkwaardige verschijnsel dat de financiële factoren omzet en Return on Assets (ROA) ook met één jaar vertraging afhankelijk zijn van zichzelf. Dit fenomeen staat in de financial accountingliteratuur bekend als 'earnings persistence' (zie bijvoorbeeld Collins en Kothari, 1989). Het hier geschetste beeld geeft de afhankelijkheden weer tussen de vier BSC-dimensies van prestaties op het niveau van de gehele onderneming. Waarschijnlijk zullen deze bedrijven voor de prestatiemeting van afzonderlijke business units gebruikmaken van weer andere scorecards. Tevens is het van belang hier op te merken dat het om een totaalbeeld gaat van een populatie van zeer verschillende ondernemingen. Wellicht dat de BSC van ondernemingen in specifieke sectoren geheel eigen en afwijkende causale relaties vertonen. Ten slotte worden in dit onderzoek jaarcijfers gebruikt. Het is goed

Figuur 3. Relaties tussen de BSC dimensies op ondernemingsniveau (Bryant et al., 2000)

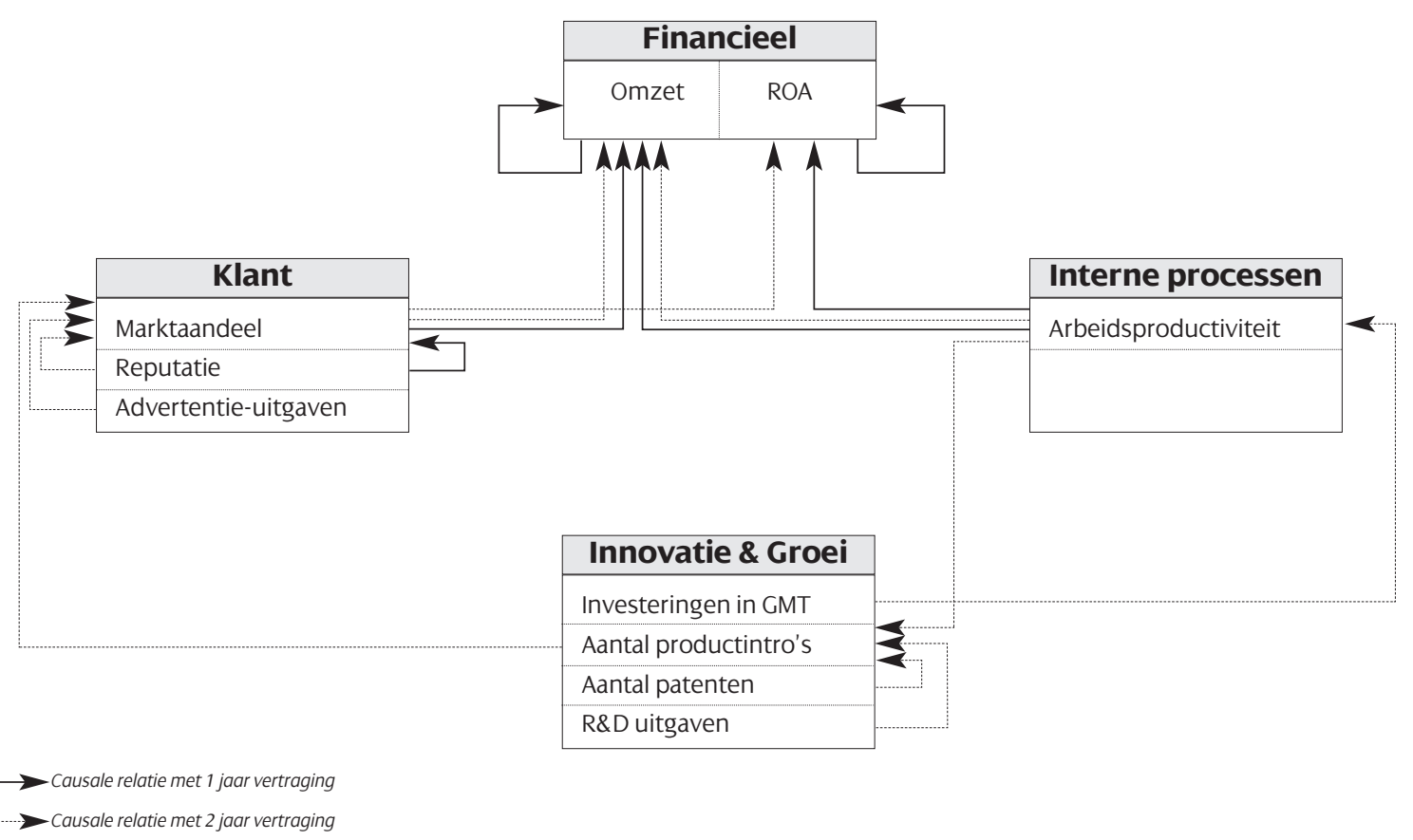


mogelijk dat deze relatief lange periode veel causale relaties met een kortere vertraging niet opspoort. Dit kan een verklaring zijn voor het feit dat relatief weinig operationele afhankelijkheden zijn opgemerkt.

Een onderzoek van Groot (2001) onder 54 Nederlandse beursgenoteerde ondernemingen richt zich wél op de prestatiebeoordeling van business units en maakt daarbij onderscheid tussen type bedrijven. Bij de beoordeling van de meest belangrijke waardecreërende afdelingen (dus geen inkoop-, verkoop- of marketingafdelingen) maken dienstverlenende bedrijven duidelijk minder gebruik van operationele en zachte ('softe') maatstaven dan productiebedrijven. Operationele maatstaven zijn bijvoorbeeld efficiëntie, kwaliteit en het nakomen van productieschema's. Zachte prestatiemaatstaven zijn onder andere de wijze waarop een manager zijn medewerkers motiveert en de kwaliteit van de relatie die hij met hen onderhoudt. Bij een agressieve strategie voor het vergroten van marktaandeel wordt meer gewicht toegekend aan accountingmaatstaven (zoals omzet, winst, kosten, brutomarge) en zachte maatstaven. Zachte maatstaven worden ook belangrijker bij een strategie van productinnovatie. Nederlandse ondernemingen die in de financiële dimensie succesvol zijn (gemeten aan de appreciatie van de beurswaarde) blijken een strategie van productinnovatie te volgen. Het gebruik van relatief meer operationele informatie voor de prestatiebeoordeling leidt verrassend genoeg tot verlaging van de beurswaarde. Aangezien dit onderzoek zich richt op grote ondernemingen ligt het voor de hand dat het topbestuur een zekere afstand tot de business units bewaart. De ondernemingen die dan tóch nog gebruikmaken van operationele maatstaven bemoeien zich kennelijk méér dan gebruikelijk met de interne gang van zaken in hun business units. Dit kan een indicatie zijn van problemen die door de business units niet meer zelfstandig kunnen worden opgelost en die ook verantwoordelijk zijn voor de lagere beurswaarde.

\section{Het gebruik van de BSC}

Het ontwerpen van een goede BSC blijkt niet gemakkelijk te zijn (zie voor enkele praktijkvoorbeelden Ewing, 1996; Groot, Van Manen, Menkhorst, Roozen en Til, 2000; Mensink, 1997). Toepassing van de BSC kan worden onderzocht op twee niveaus, namelijk op individueel niveau en op organisatieniveau. Op het individuele niveau gaat het om de vraag welke rol de BSC speelt bij het ondersteunen van de individuele beslisser in het waarnemen en interpreteren van informatie en in het nemen van beslissingen. Op organisatieniveau gaat het veeleer om de rol die de BSC speelt in planning- en beheersingsbeslissingen waarbij meerdere actoren in de organisatie zijn betrokken.

Voor een individuele beslisser presenteert de BSC twee soorten informatie: gemeenschappelijke informatie en unieke informatie. Gemeenschappelijke informatie komt in gelijkaardige vorm voor in prestatieoverzichten van meerdere eenheden. Dit geldt vooral voor financiële informatie: de meeste afdelingen in organisaties hebben dezelfde financiële prestatie-indicatoren, zoals nettowinst, operationele kosten, omzet en rendement. Unieke informatie komt in een enkele eenheid voor en kan alleen in de context van die eenheid worden geïnterpreteerd. Dit geldt vaak voor niet-financiële informatie, zoals kwaliteit van producten, innovatie van processen en betrouwbaarheid van leveringen. Uit een experiment waarin managers de relatieve prestaties van verschillende eenheden moesten beoordelen, blijkt dat managers aan de gemeenschappelijke informatie een relatief groter gewicht en aan unieke informatie een kleiner gewicht toekennen (Lipe en Salterio, 2000). In de praktijk betekent dit dat als managers de taak krijgen prestaties van verschillende eenheden aan de hand van de BSC met elkaar te vergelijken, de financiële (gemeenschappelijke) informatie naar alle waarschijnlijkheid de nietfinanciële (unieke) informatie domineert. En dat is nou net in tegenspraak met de bedoeling van de BSC!

Gebruik van de BSC voor planning en control heeft het voordeel dat organisaties meer mogelijkheden hebben de strategie te verduidelijken, werknemers te motiveren en ze (daardoor) aan te zetten tot betere prestaties. Een gevalsstudie van de introductie van de BSC in een groot Amerikaans bedrijf laat zien dat fouten in het ontwerp van de BSC tevens tot aanzienlijke problemen leiden. In deze casus gaven enkele prestatie-indicatoren geen goed beeld van de dimensies die zij geacht werden te meten en leverde de wijze waarop sommige indicatoren werden gemeten, geen betrouwbare informatie op. Deze situaties leidden vervolgens tot verkeerde prestatienormen, tot verminderde motivatie en tot spanning en conflicten tussen de verschillende managementniveaus (Malina en Selto, 2000). Ook blijken sommige prestatie-indicatoren tegen elkaar in te werken: in vijftig Amerikaanse telecommunicatiebedrijven blijkt het verhogen van het aantal (rendabele) bedrijfsaansluitingen direct ten koste te gaan van de kortetermijnReturn-on-Assets (Banker, Chang, Janakiraman en 
Konstans, 2002). Het benadrukken van het belang van ROA motiveert in deze gevallen managers tot een verlaging van het aantal bedrijfsaansluitingen, terwijl deze aansluitingen nu juist de winstgevendheid op de langere termijn verbeteren.

Het met elkaar in verband brengen van de verschillende prestatiedimensies blijkt in de praktijk een belangrijk vraagstuk te zijn. In een recente studie onder 36 managers van winstcentra in Australische productiebedrijven ontdekt Lillis (2002) vijf manieren waarop managers in hun dagelijkse besturing de BSC hanteren. In afnemende frequentie van vóórkomen zijn dit: (a) minder belang hechten aan afwijkingen op de verschillende dimensies; (b) het in technische zin aanpassen van productiesystemen zodat kwalitatieve prestatiedoelstellingen (zoals kwaliteit en snelheid) worden bereikt (men noemt dit ook wel het 'inbouwen van kwaliteit' in productiesystemen); (c) het toekennen van gewichten aan de onderscheiden prestatiedimensies om zo tot een gewogen totaalbeoordeling te komen; (d) het veranderen van de organisatiestructuur zodat zelfsturende teams meer prestatiedimensies effectief kunnen beïnvloeden en (e) het ontwikkelen van samengestelde prestatiemaatstaven, zoals 'kosten per klanttevredenheid-verbetering', waardoor beoordeelden zelf een afweging tussen de factoren van deze ratio kunnen maken. Overigens zijn niet alle besturingsvarianten even succesvol bij het ten uitvoer brengen van de strategie. Zo blijken de varianten (a) 'het minder belang hechten aan afwijkingen' en (c) 'het toekennen van gewichten aan prestatiedimensies' soms niet goed te werken bij een strategie gericht op het verbeteren van de responsiviteit op klanten en verhogen van de kwaliteit van producten.

\section{Besluit}

De in dit artikel bijeengebrachte literatuur bevat veel informatie over recente ervaringen met het gebruik van de BSC. Het totaalbeeld dat hieruit ontstaat, geeft tevens de mogelijkheid enkele concrete aanbevelingen voor een goed gebruik van de BSC te doen.

Zo is het aan te bevelen niet één identieke BSC voor alle organisatieonderdelen te gebruiken, maar specifieke BSC's te ontwerpen voor verschillende functies, organisatieniveaus en planningsperioden. Dit introduceert overigens wél twee additionele problemen. Om het totale beleid van de organisatie op gecoördineerde wijze gericht te houden op gezamenlijke organisatiedoelstellingen, is het van belang de afzonderlijke BSC's op elkaar aan te laten sluiten. Daarnaast is er een probleem van de onderlinge beoordeling van de prestaties van de afzonderlijke eenheden: de centrale manager moet in deze beoordeling inherent onvergelijkbare BSC's met elkaar vergelijken. Zoals we hebben gezien, nemen veel beslissers daarin toch snel hun toevlucht tot gemeenschappelijke, meest financiële, informatie.

Een tweede aanbeveling is om bij het ontdekken van de causale relaties in het bedrijfsmodel bedacht te zijn op allerlei soorten afhankelijkheden. Het is van belang verder te kijken dan de direct-lineaire relaties, en ook bedacht te zijn op niet-lineaire, stapsgewijze, vertraagde en circulaire relaties tussen variabelen.

Ten slotte wordt nu eveneens duidelijk dat toepassing van de BSC veelal geen geïsoleerde operatie is. Voor een succesvolle toepassing van de BSC is het nodig om de introductie te begeleiden door wijzigingen in besturings- en productiesystemen. Hierbij kan men denken aan veranderingen in het beoordelings- en beloningssysteem, wijzigingen in de organisatiestructuur (bijvoorbeeld het werken in zelfsturende teams) en aanpassing van productieprocessen (zoals het 'inbouwen' van kwaliteit in productiesystemen). Ontwerp en invoering van een BSC wordt hierdoor niet alleen een taak voor controllers en accountants, maar vereist ook de deelname van technici, organisatiekundigen en managers. Hierdoor kan de BSC een veelbelovend instrument worden voor integrale sturing van organisaties.

\section{Literatuur}

American Institute of Certified Public Accountants en L.S. Maisel, (2001), Performance measurement practices survey results, AICPA, Jersey City, NJ.

Banker, R.D., H. Chang, S.N. Janakiraman en C. Konstans, (2002), A balanced scorecard analysis of performance metrics (working paper), School of Management, The University of Texas at Dallas.

Banker, R.D., C. Konstans en R. Mashruwala, (2000), A contextual study of links between employee satisfaction, employee turnover, customer satisfaction and financial performance. Paper presented at the AAA Annual Conference, Philadelphia.

Behn, B.K. en R.A. Riley, (1999), Using non-financial information to predict financial performance: the case of the US airline industry, in: Journal of Accounting, Auditing \& Finance, 14 (1), pp. 29-56.

Bruns Jr., W. J. en S.M. McKinnon, (1993), Information and Managers: A Field Study, in: Journal of Management Accounting Research, 5, pp. 84-108.

Bryant, L., D. Jones en S.K. Widener, (2000), The Balanced Scorecard: A Cross-sectional Investigation of Lead/Lag Relations, Paper presented at the AAA Annual Conference, Philadelphia.

Buzzell, R.D. en B.T. Gale, (1987), The PIMS Principles, The Free Press, New York.

Collins, D.W. en S.P. Kothari, (1989), An Analysis of Intertemporal and Cross-sectional Determinants of Earnings Response Coefficients, in: Journal of Accounting and Economics 11, pp. 143-181.

Dresner, M. en K. Xu, (1995), Customer service, customer satisfaction and 
corporate performance in the service sector, in: Journal of Business Logistics.

Ewing, P., (1996), The Balanced Scorecard at ABB Sweden, A Management System in a 'Lean Enterprise', Paper presented at the 19th Annual Congress of the European Accounting Association, Bergen, Norway.

Gale, B.T., (1992), Monitoring Customer Satisfaction and Market-Perceived Quality (American Marketing Association Worth Repeating Series 922CSO I), American Marketing Association, Chicago.

Gordon, L.A. en V.K. Narayanan, (1984), Management Accounting Systems, Perceived Environmental Uncertaincy and Organization Structure, in: Accounting, Organizations and Society, 9 (1), pp. 33-47. Govindarajan, V. en A.K. Gupta, (1985), Linking control systems to business unit strategy: impact on performance, in: Accounting, Organizations and Society, 10 (1), pp. 51-66.

Groot, T.L.C.M., (2001), Environmental Uncertainty, Corporate Strategy, Performance Measurement and the Creation of Economic Value (Research Memorandum ARCA-RM-01-13), ARCA, Vrije Universiteit, Amsterdam.

Groot, T.L.C.M., J.T. van Manen, C.J. Menkhorst, F.A. Roozen en G.E.A. van Til, (2000), De Balanced Scorecard, Theorie, toepassingen en ervaringen, Vol. 38, Kluwer, Deventer.

Hopper, T., L. Kirkham, T.W. Schapens en S. Turley, (1992), Does financial accounting dominate management accounting - a research note, in: Management Accounting Research, 3 (4, December), pp. 307-311.

IQS, (1991), International Quality Study: The definitive study of the best international quality management practices, Ernst \& Young and American Quality Foundation, Cleveland, $\mathrm{OH}$.

Ittner, C.D. en D.F. Larcker, (1998a), Are Nonfinancial Measures Leading Indicators of Financial Performance? An Analysis of Customer Satisfaction, in: Journal of Accounting Research, 36 (Supplement), pp. 1-35.

Ittner, C.D. en D.F. Larcker, (1998b), Innovations in Performance Measurement: Trends and Research Implications, in: Journal of Management Accounting Research, 10, pp. 205-238.

Johansson, C., G. Nilsson, J. Nilsson en L.A. Samuelson, (1997), Ekonomistyrning i svenska börsbolag: En Lägesrapport om ekonomistyrningens inriktning, utformning och utveckling, Linköping University, Stockholm. Kald, M. en F. Nilsson, (2000), Performance Measurement at Nordic Companies, in: European Management Journal, 18 (1, February), pp. 113-127.

Kaplan, R.S. en D.P. Norton, (1992), The Balanced Scorecard - Measures that drive performance, in: Harvard Business Review (January-February), pp. 71-79.

Kaplan, R.S. en D.P. Norton, (1993), Putting the balanced scorecard to work, in: Harvard Business Review (September/October), pp. 134-147.

Kaplan, R.S. en D.P. Norton, (1996a), The Balanced Scorecard, Harvard Business Press, Boston.

Kaplan, R.S. en D.P. Norton, (1996b), Using the Balanced Scorecard as a strategic management system, in: Harvard Business Review (JanuaryFebruary), pp. 75-85.

Lillis, A.M., (2002), Managing mulitple dimensions of manufacturing performance - an exploratory study, in: Accounting, Organizations and Society, 27 (6, August), pp. 497-529.

Lingle, J.H. en W.A. Schiemann, (1996), From Balanced Scorecard to Strategic Gauges: is Measurement Worth It?, in: Management Review (March), pp. 56-61.
Lipe, M.G. en S.E. Salterio, (2000), The Balanced Scorecard: Judgmental Effects of Common and Unique Performance Measures, in: The Accounting Review, 75 (3, July), pp. 283-298.

Malina, M.A. en F.H. Selto, (2000), Communicating and Controlling Strategy: an empirical study of the effectiveness of the Balanced Scorecard, Paper presented at the AAA Annual Conference, Philadelphia.

McKinnon, S.M. en W.J. Bruns Jr., (1992), Management Information and Accounting Information: What do Managers want?, in: Advances in Management Accounting, 1, pp. 55-80.

Mensink, H.D.J., (1997), Prestatiemeting bij de KLM, in: L. Traas en E. de With (red.), Handboek Management Accounting (pp. D1818-1811-1818), Samsom Bedrijfsinformatie, Amsterdam.

Nørreklit, H., (2000), The balance on the balanced scorecard - a critical analysis of some of its assumptions, in: Management Accounting Research, 11 (1), pp. 65-88.

Schefczyk, M., (1993), Operational performance of airlines: an extension of traditional measurement paradigms, in: Strategic Management Journal, 14, pp. 301-317.

Van der Stede, W.A., C.W. Chow en T.W. Lin, (2000), Determinants, characteristics, and outcomes of integrated performance measurement systems, Unpublished paper, University of Southern California/San Diego State University.

Stivers, B.P., T.J. Covin, N. Hall en S. Smalt, (1998), How nonfinancial performance measures are used, in: Management Accounting, 79 (February), pp. 44-49.

Zeithaml, V.A., L.L. Berry en A. Parasuraman, (1996), The Behavioral Consequences of Service Quality, in: Journal of Marketing, 60 (April), pp. 31-46.

\section{Noten}

1 Deze bedrijven waren: Advanced Micro Devices, American Standard, Apple Computer, Bell South, CIGNA, Conner Peripherals, Cray Research, DuPont, Electronic Data Systems, General Electric, HewlettPackard en Shell Canada. 